\title{
Evaluation of the impact of severity of itching symptoms on the level of depression in patients with allergic contact eczema (preliminary study)
}

\section{Ocena wpływu nasilenia świądu na poziom objawów depresji u pacjentów $z$ alergicznym wypryskiem kontaktowym (badania wstępne)}

\author{
Małgorzata Czarny-Działak¹, Ewa Latała-Łoś \\ ${ }^{1}$ Centre of Physiology and Pathophysiology, Institute of Nursing and Obstetrics, Faculty of Health Sciences, Jan Kochanowski \\ University, Kielce, Poland \\ Head of the Centre: Prof. Robert Bucki MD, PhD \\ ${ }^{2}$ Regional Occupational Health Centre, Kielce, Poland \\ Head of the Centre: Ewa Latała-Łoś MD, PhD
}

Studia Medyczne 2014; 30 (2): 106-110

Key words: allergic contact dermatitis, depression, itching.

Słowa kluczowe: alergiczny wyprysk kontaktowy, depresja, świąd.

\begin{abstract}
Introduction: Allergic contact dermatitis is one of the most frequent skin disorders in the general population as well as among people who work professionally. Allergic contact allergens are simple chemical compounds. The most common are nickel and fragrance substances.

Aim of the research: To estimate if and how the degree of itching in allergic contact dermatitis influences the development of depression.

Material and methods: The treatment was conducted on a group of 17 people with allergic contact dermatitis. Each person was treated in order to estimate the level of depression using Becks scale and the level of itching. Next, it was estimated if the level of itching had any influence on the development of depression.

Results: All skin diseases, including allergic contact eczema affect the biological and psychosocial functioning, and the quality of human. Five patients out of 17 showed features of depression: 3 mild ( 2 men and 1 woman), which is the most common state of transition, and 2 (women) moderately-severe depressive symptoms. Both patients with moderately-severe depressive symptoms had a significant degree of severity of pruritus.

Conclusions: It was stated that the level of itching has no influence on the development of depression.
\end{abstract}

\section{Streszczenie}

Wprowadzenie: Alergiczny wyprysk kontaktowy (AWK) jest jedną z częstszych dermatoz występujących zarówno w populacji ogólnej, jak i w grupie osób pracujących zawodowo. U kobiet do uczulenia dochodzi częściej. Czynnikami uczulającymi - alergenami kontaktowymi, są proste związki chemiczne - hapteny, które stają się pełnowartościowymi alergenami dopiero po związaniu z białkami skóry. Do najczęściej uczulających substancji należą nikiel i środki zapachowe. Cel pracy: Ustalenie związku między stopniem nasilenia świądu w przebiegu AWK a poziomem objawów depresyjnych. Materiał i metody: Badania o charakterze wstępnym przeprowadzono w 17-osobowej grupie chorych na AWK. U każdej z tych osób oceniano stopień nasilenia objawów depresyjnych za pomocą skali Becka, stopień nasilenia świądu oraz zależność między tymi stanami klinicznymi. Następnie sprawdzano, czy stopień nasilenia świądu wiąże się z objawami depresyjnymi.

Wyniki: W licznych publikacjach podkreśla się, że choroby skóry w różnym stopniu wpływają na funkcjonowanie fizyczne, psychiczne i społeczne pacjenta. Wśród 17 chorych na AWK stwierdzono objawy depresyjne u 5 chorych, w tym u 3 łagodne, u 2 umiarkowanie ciężkie. U chorych z objawami depresji występował znacznie nasilony świąd.

Wnioski: Stwierdzono związek między nasileniem świądu a samooceną depresji. 


\section{Introduction}

Generally, eczema is an acquired, superficial inflammation of the skin caused by external factors.

Taking into account the mechanism of allergic contact dermatitis (ACD), in clinical practice irritation eczema and allergic eczema can be distinguished depending on the existence of allergic reaction. Both eczemas may also coexist. Frequently, the pathogenesis of this phenomenon involves the irritant contact dermatitis (due to damaged skin caused by inflammation) paving the way for allergens to facilitate the development of allergic contact dermatitis [1].

All skin diseases, including allergic contact eczema, affect the persons's biological and psychosocial functioning and quality of life [2]. The relationship between skin diseases and psychological factors is complex [3]. All diseases can affect quality of life, but skin diseases are unique in this regard as the most visible, thus they can trigger off a significant number of complexes among patients what affects quality of life and possible development of depression. Additionally, some skin diseases, such as ACD, are combined with a different, sometimes considerable escalation of pruritus, and this can translate into a reduction in quality of life, or the development of depression.

Allergic contact dermatitis incidence is about $1 \%$ to $10 \%$ in the general population; it occurs more frequently in the population of patients with atopic dermatitis - up to $43 \%$ [4]. A factor contributing to the development of ACD in patients with atopic dermatitis is a skin disorder protective function that favours the penetration of allergens. Allergic contact dermatitis allergens are haptens or incomplete allergens which, after penetration into the skin and connection to acarrier protein, acquire features of a full allergen. Therefore, the development of ACD requires direct skin contact with the hapten $[1,5,6]$. After penetration through the skin it is absorbed by the so-called antigen presenting cells (APC). Antigen presenting cells begin the process of the development of a type IV hypersensitivity reaction, which is an immune mediated ACD. This cyclisation reaction depends on the number and activity of antigen presenting cells, mainly in the skin, which are known as Langerhans cells. If the amount of Langerhans cells is small the possibility of appearance of allergic contact dermatitis is low. A reverse type of phenomenon occurs in people with active changes in atopic dermatitis, in whom Langerhans cells are no longer able to stimulate - due to active inflammation - and therefore such people have a greater readiness to participate in hypersensitivity type IV reaction [4] When combined with the allergen, Langerhans cells migrate to regional lymph nodes and present the allergen Th1 lymphocytes. Then the sensitised lymphocytes migrate to the skin, causing pathological changes. Due to the fact that, in ACD is mediated immune response by Th1 immune memory is permanent, which means that the lesions appear after each contact with the allergen. The most common contact allergens include metals (nickel, chromium and cobalt), rubber additives and perfumes $[1,5]$.

The most common symptom is itching with varying degrees of severity, and the most severe inflammatory pruritic conditions are often accompanied by pain. Symptoms include inflammation of the superficial epidermis and dermis and the presence of characteristic evolutionary multiformity. Typical morphological changes include exudative lumps on erythematous base. These lumps can transform into bubbles, which can burst and cause erosions - forming larger areas that ooze with secretions. The drying secretions form scabs. Long-acting causal factors may produce lichenification - the skin becomes thicker with depth fissures visible as darker areas. Outbreaks of eczema are usually located at the site of skin contact with the allergen and are not sharply demarcated, and they usually disappear without scarring. Rarely, they can include a larger surface area, particularly if the formation develops into erythroderma [1]. Typically, the course is chronic, with three recurrent periods: acute, subacute and chronic. Each period has its own characteristic morphological changes. The acute phase is dominated by acute inflammation and the presence of a large number of papules and erosions. In the subacute phase, inflammation occurs to a lesser degree with scabs and peeling. During the chronic phase, lichenification signs predominate [1]. Recognition is based on the patient's history, clinical signs and positive patch-test results. These tests are performed by placing a small amount of hapten on the skin (usually on the back) for a period of $48 \mathrm{~h}$ [6]. Readings are taken after $48 \mathrm{~h}$ and $72 \mathrm{~h}$. Very rarely it is necessary to perform a histopathological examination [1]. The ACD should be primarily differentiated from irritant eczema but also from seborrheic, dyshidrotic, cornifying, nummular, crural eczema, contact eczema protein and atopic dermatitis $[1,6]$.

Prognosis: Due to the fact that the memory immune response in type IV is long lasting, the symptoms recur after each contact with the allergen throughout the life of the patient. Therefore, the possibility of self-healing does not occur, and the waveform is chronic and recurrent. The occurrence of symptom-free periods and their duration depends on the patient's adherence to treatment recommendations - avoidance of contact with the allergen and proper care of dry skin [1].

Treatment is based on the elimination or if this is not possible, avoidance, of exposure to allergens and irritants, proper skin care, treatment and in some cases outside photochemotherapy or systemic treatment. Detection of allergen sensitisation and its elimination from the environment of the patient is very important, especially when it is impossible to maintain min- 
imum contact of the patient with the provoking factor. It is also extremely important to protect the skin against drying; this invloves frequent use of emollients and proper selection of cosmetic agents. External treatment is based essentially on the use of topical corticosteroids in various forms depending on the activity of the inflammatory process. Another possibility is the use of calcineurin inhibitors - tacrolimus or pimecrolimus. Phototherapy or photochemotherapy causes transient improvement over a period of several months by decreasing the number of Langerhans cells in the skin, which reduces the possibility of appearance of ACD. The general treatment includes the use of antihistamines to relieve the symptoms of itching, antibiotics in the case of secondary bacterial infections, corticosteroids only in severe cases and immunosuppressive drugs for the most serious, refractory cases $[1,7]$.

\section{Aim of the research}

The aim of the study was to determine whether there is a relationship between itching in the course of the AWK and the occurrence of depressive symptoms.

\section{Material and methods}

The study is preliminary. Participation in the study was voluntary. The study was conducted on 17 patients ( 5 men and 12 women) with personal allergic contact eczema. The small size of the group of patients enrolled in the study is associated with the presence of numerous exclusion criteria. The most important selection criterion in the study was the possibility to make patch testing - patients with extensive skin lesions were not included in the study. Also, people who were earlier diagnosed with depression or any other mental illness (which may affect the outcome of the Beck scale) were not included the study. Patients whose pruritus was due to another cause were also excluded. The study was started in June 2011 and is currently ongoing, so the results obtained here are preliminary. Patients who were gathered for the study group ranged in age from 21 to 68 years. Persons under 18 years of age, due to the generally greater reactivity of their skin, and those above 70 years of age, due to the generally lower reactivity of their skin and their propensity to develop depression, were also excluded form the study. It is noteworthy that among the patients enrolled in the study there were only 5 men, but there were 12 women - our own observations suggest that women seek medical attention more often and earlier, while men often appear with a significant degree of severity of changes - so they could not be enrolled in this study. Persons included in the study were patients from the "Healthy Lungs" Allergy Clinic. To assess depressive symptoms in patients with this dermatosis, a questionnaire was used: the Beck depression scale. It is a scale that is usually used for self-assessment of depression. It consists of 21 points scored from 0 to 3 and contains questions for patient evaluation including self-satisfaction, the presence of any suicidal thoughts, tendency to cry, nervousness, sleep disturbances, appetite and current physical fitness [10]. Due to the simplicity of the questions, this questionnaire can be addressed to virtually any patient, which is a huge advantage and increase its usefulness in the outpatient setting. The scale was filled in by every patient in about $20 \mathrm{~min}$. In addition, patch testing was performed on each patient with the use of basic European set (28 allergens). The tests were performed in accordance with generally accepted standards on the backs' skin, by placing a layer of absorbent paper (each with an area of $1 \mathrm{~cm}^{2}$ ) at a distance of at least $2 \mathrm{~cm}$, soaked allergen. The tests were read after 48 and $72 \mathrm{~h}-$ also, in case of positive results, to verify on $7^{\text {th }}$ day. The evaluation of skin lesions was based on the following criteria: lack of response - 0; erythema + ; erythema and papules - + +; erythema, papules and vesicles -+++ ; and attractive infiltration and bubbles -++++ . Patients, prior to the test, for a period of 3 weeks, had discontinued medication that could have led to false results, e.g. by weakening skin reactivity. In particular, these included antihistamines and lime formulations. Patients were also assessed for severity of pruritus via visual analogue scale (VAS). This is a popular scale evaluating the severity of a variety of ailments, not just itching skin. This scale comprises a score from 0 to 10 , by means of which the patient assesses the severity of the observed symptom/s in the course of the disease, pruritus in this case. The greater the severity of symptom/s, the higher the score on the VAS. Subsequently, the degree of depressive symptoms was compared to the degree of severity of pruritus, in order to assess whether the severity of the itching was associated with depressive symptoms. Integrating criterion for testing were as follow: a history of ACD and the presence of lesions typical for ACD, and positive patch test for at least one allergen tested - for negative test results but with the presence of the evocative medical history, which indicates the dermatosis and typical for it skin lesions, the tests were repeated. In the case of repeated negative tests, the patient was excluded from the study. The study also excluded patients with acute infectious diseases, cancer, autoimmune diseases, immune disorders, and with escalation of dermatosis (may cause erythroderma) as well as patients in whom the effect of environmental factors could contribute to the severity of depressive symptoms.

\section{Results}

Five patients out of 17 patients showed features of depression: in 3 mild ( 2 men and 1 woman), which is 
Table 1. The relationship between the severity of itching and the occurrence of depressive symptoms

\begin{tabular}{|lcc|}
\hline Parameter & $\begin{array}{c}\text { Patients without depressive } \\
\text { symptoms }\end{array}$ & $\begin{array}{c}\text { Patients with depressive } \\
\text { symptoms }\end{array}$ \\
\hline Total number of patients & 12 & 5 \\
\hline $\begin{array}{l}\text { Number of patients with significant increase } \\
\text { in pruritus }\end{array}$ & 0 & 4 \\
\hline $\begin{array}{l}\text { Number of patients with an average severity } \\
\text { of pruritus }\end{array}$ & 1 & 1 \\
\hline Number of patients with low severity of pruritus & 11 & 0
\end{tabular}

the most frequently a transitional state, connected with condition of a patient.

Two women had moderately severe depressive symptoms requiring psychiatric consultation. The remaining subjects did not exhibit characteristics of depression. Both patients with moderately severe depressive symptoms had a significant degree of severity of pruritus (analogue scale of 10 points), and in the contact allergic patch tests they showed reaction to at least two allergens ( 1 patient to nickel and cobalt and the other to chromium, nickel, fragrance cocktail sulphate neomycin and p-phenylenediamine). In contrast, the patients with mild depressive symptoms had a significant degree of severity of pruritus - analogue scale 8 , the second - analogue scale 7, while the average degree of illness was 5 . These patients had a positive patch test to at least one allergen - 1 male patient to chromium and nickel, and the second to benzocaine and p-phenylenediamine, the female patient to p-phenylenediamine. Patients' not exhibiting characteristics of depression usually have a low degree of severity of pruritus, up to 3 points. The degree of escalation of pruritus was 5 at only 1 female patient from this group. Among this group of patients in the 3 cases patch tests were negative at the first test and at the second attempt tests were positive to at least one allergen, the remaining tests were positive to at least one tested allergen: one patient to chromium, 2 patients to p-phenylenediamine, 3 women to mixture of fragrance, 3 female patients to nickel and cobalt (Table 1).

\section{Discussion}

A growing number of studies devoted to the assessment of quality of life are being published in the medical context. This includes the evaluation of depression as a variable that can have an impact on quality of life [2]. The results indicate that the skin responds to sensory stimuli and participates in the expression of emotion, which is the reason why it plays an important role in shaping self-esteem [2]; it can also be connected with the possibility of lowering self-esteem, and therefore also with the possibility of developing depression. Currently it is a well-known fact that there is a relationship between diseases of the skin and the psyche of a person. This relation consists of mutual interaction - dermatological diseases affect the psyche, and a person's mental state affects their skin [11]. Some symptoms, which seem to affect only the skin, may in fact be mental disorders, such as parasitic insanity. At the same time, there are dermatological disorders that can be caused by the psyche, e.g. idiopathic pruritus [11]. So we can see that different mechanisms can be involved in the development of pruritus; namely the psyche, factors involving the skin or metabolic disorders. In the literature it is emphasised that skin diseases affect the functioning of the patient (not only biologically but also mentally and socially) with varying degrees. This impact does not have to be dependent on the degree of severity of lesions [2]. There are diseases of the skin, which affect quality of life more than others. Thus a number of examinations are undertaken in order to determine this by estimating the factors that may influence quality of life, including depression as a patient's personality factor [2]. For example, it was found that atopic dermatitis favours the development of depression [12]. Research by Cvetkovski et al. also showed that severe allergic contact dermatitis has a significant impact on quality of life and can promote the development of depressive symptoms [13]. Similarly, studies by Kieć-Świerczyńska confirmed that skin diseases such as contact dermatitis or atopic dermatitis can diminish quality of life [3]. Beck's scale is one of the most popular scales used to assess depressive symptoms [14-16]. It is also universally used to evaluate depressive symptoms among patients with skin diseases, and in this work the Beck scale was used as well. Our findings suggest that the severity of pruritus can have an impact on the development of depressive symptoms.

\section{Conclusions}

The presence and severity of both itching and depressive symptoms in a group of patients suffering from allergic contact eczema suggests the coexistence of a positive relationship between the two conditions. However, confirmation of the effects of observation and demonstration of the impact of the severity of itching on the development of depressive states re- 
quire further verification and extensive research supported by statistical analysis.

To summarize the research - these were merely observations conducted on a small group. No statistical tests were applied from which the relationship between variables could be clearly stated. Therefore, we can only suggest that such a relationship does exist; however, it requires verification in further studies.

\section{References}

1. Mędrala W. Allergic contact dermatitis. In: Fundamentals of allergology. Mędrala I (ed.). Górnicki Medical Publishing House, Wrocław 2006; 271-8.

2. Baranowska A, Krajewska-Kulak E , Szyszko-Perłowska A, et al. The problem of quality of life in dermatology. Nursing 2011; 19: 109-15.

3. Kieć-Świerczyńska M, Potocka A. Psychological factors in allergic diseases of the skin. Occupational Medicine 2008; 59: 279-85.

4. Snowstorm R, Wanat-Bush M. Atopic dermatitis. Krakow 2007; 80-94.

5. Singer R. Contact allergy - diagnosis and treatment. Allergy Asthma Immunology 2007; 3: 1-6.

6. Singer R. Contact eczema. Postep Derm Alergol 2009; 26 375-7.

7. Salek MS, Finlay AY, Luscombe DK, et al. Cyclosporin greatly Improves the quality of life of adults with severe atopic dermatitis. A randomized, double-blind, placebocontrolled trial. Br J Dermatol 1993; 129: 422-30.

8. Kulczycka L, Sysa-Jędrzejowska A. Quality of life in patients with systemic lupus erythematosus with particular emphasis on research methodology. Progress Hig Med Exp 2007; 61: 472-7.

9. Szepietowski J, Solomon J, Finlay A, et al. Impact indicator of skin disorders on quality of life - Dermatology Life Quality Index (DLQI): Polish language version. Clin Dermatol 2004; 6: 63-70.

10. Jagielska I, Grabiec M, Bartholomew Z, et al. The prevalence of symptoms of depression in climacteric women in the postmenopausal period. Menopausal 2007; 3: 140-4.

11. Lipczyński A. The role of psychological factors in the development and course of dermatological conditions. Psychology net.pl

12. Hashiro M, Okumura M. The relationship between the psychological and immunological state in people team with atopic dermatitis. J Dermatol Sci 1998; 16: 231-5.

13. Cvetkovski RS, Zachariae R, Olsen JI, et al Quality of life and depression in a population of occupational hand eczema patients. Contact Dermatitis 2006; 54: 106-11.

14. Bomba J. Depression in adolescents. Clinical analysis. Polish Psychiatry 1982; 1-2: 25-30.

15. Krzyżkowiak N. Depression and depressive symptoms after myocardial infarction and psychosocial factors. Polish Psychiatry 2007; 41: 679-91.

16. Kaplan HI, Sudock BJ, Sudock VA. Clinical psychiatry. Urban \& Partner, Wrocław 2004; 163.

\section{Address for correspondence:}

Małgorzata Czarny-Działak MD, PhD

Centre of Physiology and Pathophysiology

Institute of Nursing and Obstetrics

Faculty of Health Sciences

Jan Kochanowski University

ul. Malachitowa 32A, 25-705 Kielce, Poland

Phone: 602570179

E-mail: drmczarny@interia.pl 